\title{
ターレシュ／アルボルズ山系（イラン）の先史遺跡 鉄器時代以前へのアプローチ- \\ Search for the Archaeological Sites Dated before the Iron Age in the Talesh/Alborz Mountains, Iran
}

\author{
大 津 忠 ${ }^{*}$ 彦 \\ OHTSU Tadahiko
}

\section{はじめに}

イランにおける考古学研究の動向について，筆者はかつてその梗概を記し問題点の一 端を紹介したことがあった。これと前後する1990年度より1996年度まで, 中近東文化セ ンターではその研究事業の一環としてイラン各地を対象とする遺跡踏查を継続し, 考古 学的諸遺跡の現状や博物館, 関連機関の機能状況についての見聞情報収集に努めてきて いた。活動のねらいは「イラン・イスラーム革命」(1979年) 以降のイラン考古学に関す る閉塞的情報不足を少しでも補うことにあった。これらについては中近東文化センター 発行の年報『MECCJ』にそれぞれ簡報がある。しかしながら, 遺跡踏查という現地活動 および情報提供をはじめとする共同作業が不可欠であることが次第に痛感されるように なった。大津らはイランにおいて問題解決の糸口を模索するとともに, 1995年以来, 在日 イラン大使館を通じて公式に, イランでの考古学的調査活動許可申請を行い続け, さら には同大使館の助言を得て，イラン文化遺産庁宛の要望書ならびに調査活動計画案を提 示した。これらに対しては，1997年 6 月27日から同年 7 月16日までの期間，幸いにもギー ラーン州が中近東文化センターの調査隊を受け入れる形態で現地踏査が実現し，さらに 1999年 2 月 22 日から同年 3 月 14 日までの期間，補足的現地踏查を行うことが可能となっ (3) た。これはイランの現体制下では，極めて例外的かつ変則的な「外国調査隊」による考 古学的活動であったことが，イラン当局とのその後の折衝過程で判明した次第である。 しかしながらそれは我々にとって，はじめてイランにおける最新の考古学事情の一端を 濃密に直接知り得る好機ではあった。本稿では中近東文化センターによるイラン遺跡踏

* 帝京平成大学助教授, 中近東文化センター研究員 Associate Professor, Teikyo Heisei University, and Research Fellow, The Middle Eastern Culture Center in Japan 
査，とくに1997年以来継続中のギーラーン州を主とする北部イラン地域すなわちターレ シュ/アルボルズ山系域, なかでもカスピ海南および西岸域の踏査を通じて, 改めて考 えさせられた当該地域における考古学的課題のいくつかについて論じてみたい。

\section{カスピ海西岸域}

カスピ海南および西岸域に沿うターレシュ/アルボルズ山系はカスピ海からの風を遮 り，現況そこには樹林緑草地帯がひろがる。草木が通年繁茂する自然景観は，同山系よ り内陸側の沙漠を含み持つイラン高原と著しい対照をなしている。イラン地理の区分上 (4)

「Northern Highland and Caspian Lowlands」と呼称されるこの地帯では, とくに19世 紀半ばより「秘宝」と通称される古物の偶発的発見が相次いだ記録が伝わっている。も ちろんキャラールダシュト遺跡（マーザンダラーン州）やマールリーク遺跡（ギーラー ン州）などの事例のように，革命前のイラン当局が考古学的調査を行って一定の成果を 学界に寄与した遺跡もあるものの, かえってその取り組みが, この地域の宿命ともいえ る「遺跡盗掘活動」をさらに助長したという苦い経歴を併せ持つ。1959年, 第二次東大イ ラク・イラン遺跡調查団の先発隊が，テヘラーン市中においてアムラシュ（ギーラーン 州）由来と告げられた, かの正倉院伝来「瑠璃碗」と同型のガラス器およびその考古学 的重要性を洞見したのは, まさにそのころであった。いま便宜上, 当該地域を西より見 て行くと，かのモルガン兄弟（Henri and Jacques de Morgan）が「ペルシア領」ター レシュ山間域において先駆的遺跡分布調查を行い, ハサンザミニやアーグエブレル地区 において共同墓地を構成する多数の「ドルメン」を明らかにしたのは1901年であった。こ の地域において実質最初の試みともいえるモルガン兄弟による考古学的調查の成果はそ の後シェファー，ダイソンあるいは江上波夫らによって青銅器時代から鉄器時代への移 行期を考察するうえで意義付けられてきた。ターレシュ（ハシュトパル）を流れるギャ ルガーンルード川上流に位置するこのアーグエブレルでは1997年にイラン当局によって あらたに群集墓 (鉄器時代) が発掘されている。一例では, 長さ $15 \mathrm{~m}$, 幅 $2.5 \mathrm{~m}$ の石室を 巨石で構築し，被葬者は 10 人程度と考えられている。また，これより東部に位置する同 川の一支流に位置するアスブサラーでも, 紀元前 2 千年紀に遡るらしい古墓の群集が 1998年，イラン当局によって調査確認された。ここでは環状配石の中央に, 床が粘土貼り された切り石による石槨（長さ $13 \mathrm{~m}$ 前後）の例があり，追葬が認められたといわれてい る。これらはいずれも巨石を用いた群集墓という共通点があり，正式の報告書は残念な がらないものの, 類例は他所にも存在することが想定されている。確証に乏しいものの, 仮に「青銅器時代から鉄器時代への移行期」と，従前どおりの年代観を踏襲しておきた い。カスピ海西岸当該域では, 上記のような群集する古墓の存在が，ほかにシャファー 


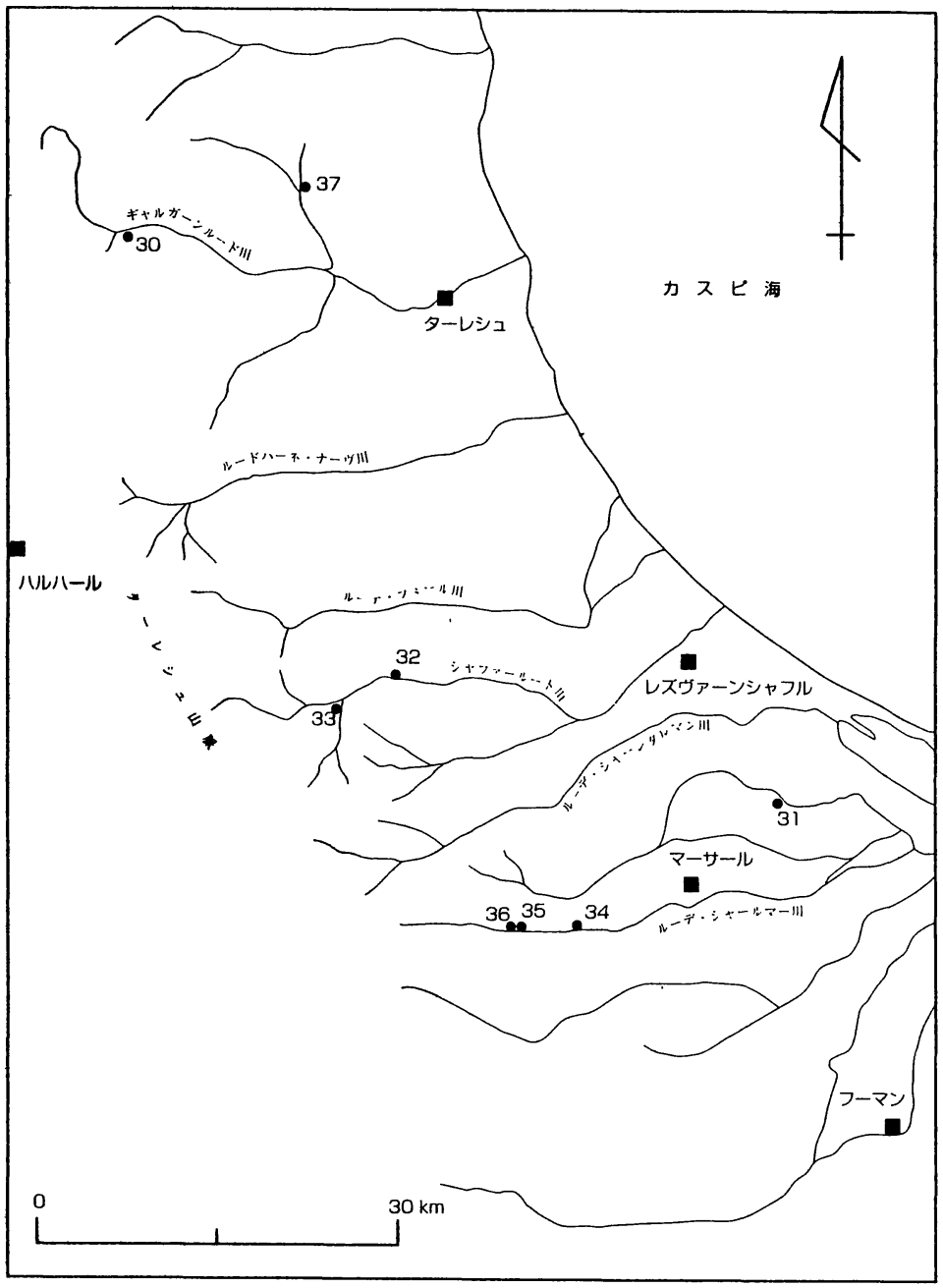
30 アーグエヴレル

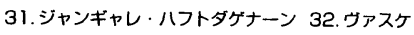
33.ミヤーンルード
34. シャールマー 35.マースーレハーニー
36. アスハリリーサ
37 アスブサラー

図 1 ターレシュ地域遺跡分布図（大津，岡野編2000，25より）

ルード川上流域のヴァスケ，ミヤーンルードおよびルーデ・シャールマー川上流域のシ ヤールマー, マースーレハーニーでも確認されている (図 1 )。ただ, 奇妙にも紀元前 2〜1 千年紀の土壙墓, 石槨墓などから成る群集墓だけがこれまで知られた遺跡形態のほとん ど唯一例であった。しかし，1997年以来継続中の遺跡踏査からふたつのことが注意され 


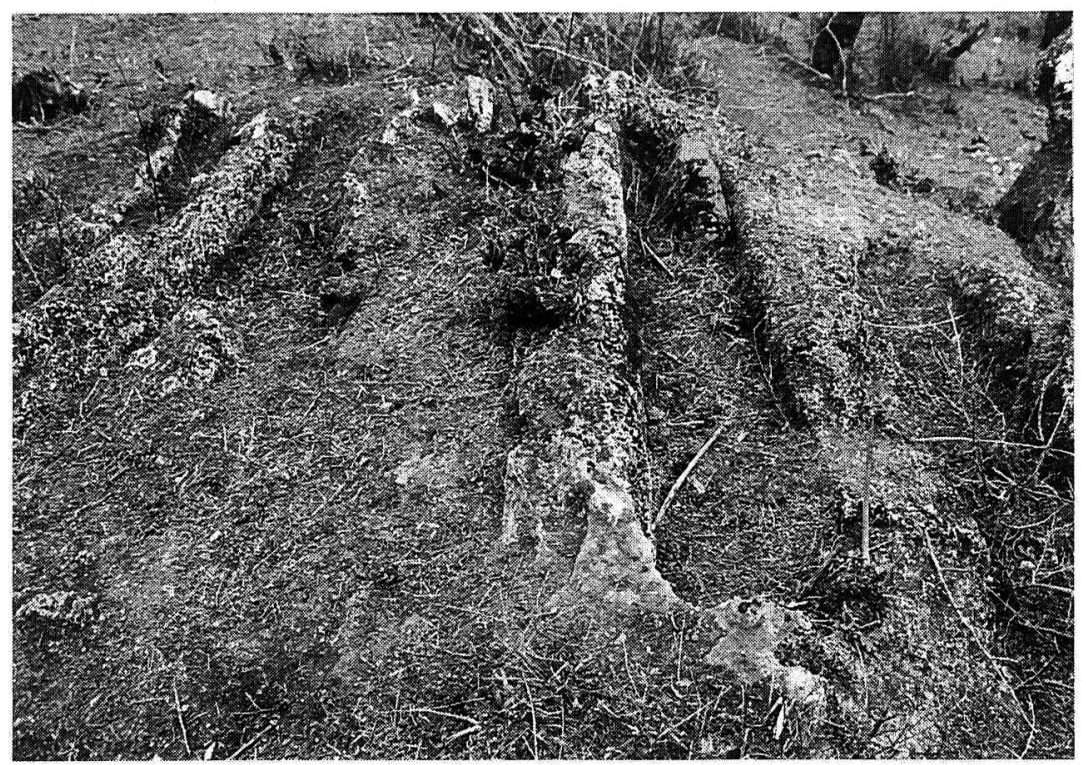

困 2 アスバリーサの「ダフメ」

る。ひとつはルーデ・シャールマー川上流域のアスバリーサ村の南東部にある「ダフメ」 の存在である。これは岩の露頭に, 約 $40 \times 220 \mathrm{~cm}$ の墓を数多く掘り込んだものである(図 2 )。山内和也の観察によれば，それはファールス地方の「ダフメ」と同様のものであり， 北部イランでは初例とのこと。もうひとつはマースーレハーニーで見られるような石灰 岩洞窟例である。ここからは人骨や石刃, 石槍が出土したといわれている。この地域に は石灰岩地帯が分布し, マーサールやソーメサラーの山間域にはすでに呼称名を有する 地点を含む 200 ヶ所にのぼる洞窟があるといわれている。残念ながら現地当局の, 洞窟人 の対処は未熟であり, ましてや洞窟以上に遺跡としての可能性が高いともいわれる「岩 陰」に対する関心，遺跡の可能性についての認識はほとんどないというのが現状である。 隣接するアーゼルバーイジャーン州以西の資料報告事例などにかんがみて, 当該地域で も新石器時代以前に遡る資料の確認をこれら洞窟遺跡に期待できるのではないだろうか。

\section{カスピ海南岸域 (図 3 )}

西岸域と基本的には同様ながら, 当該地域は組織的な発掘調查を経て, その成果が公 表されている地域, 重要遺跡を抱え持つ。たとえばセフィードルード川流域およびデイ ラマーンであり，中近東文化センターによる1997年以来継続中のギーラーン州を主とす る遺跡踏査もそれらの成果に負うところが大きい（図 4，5)。ここではふたつの点につ 


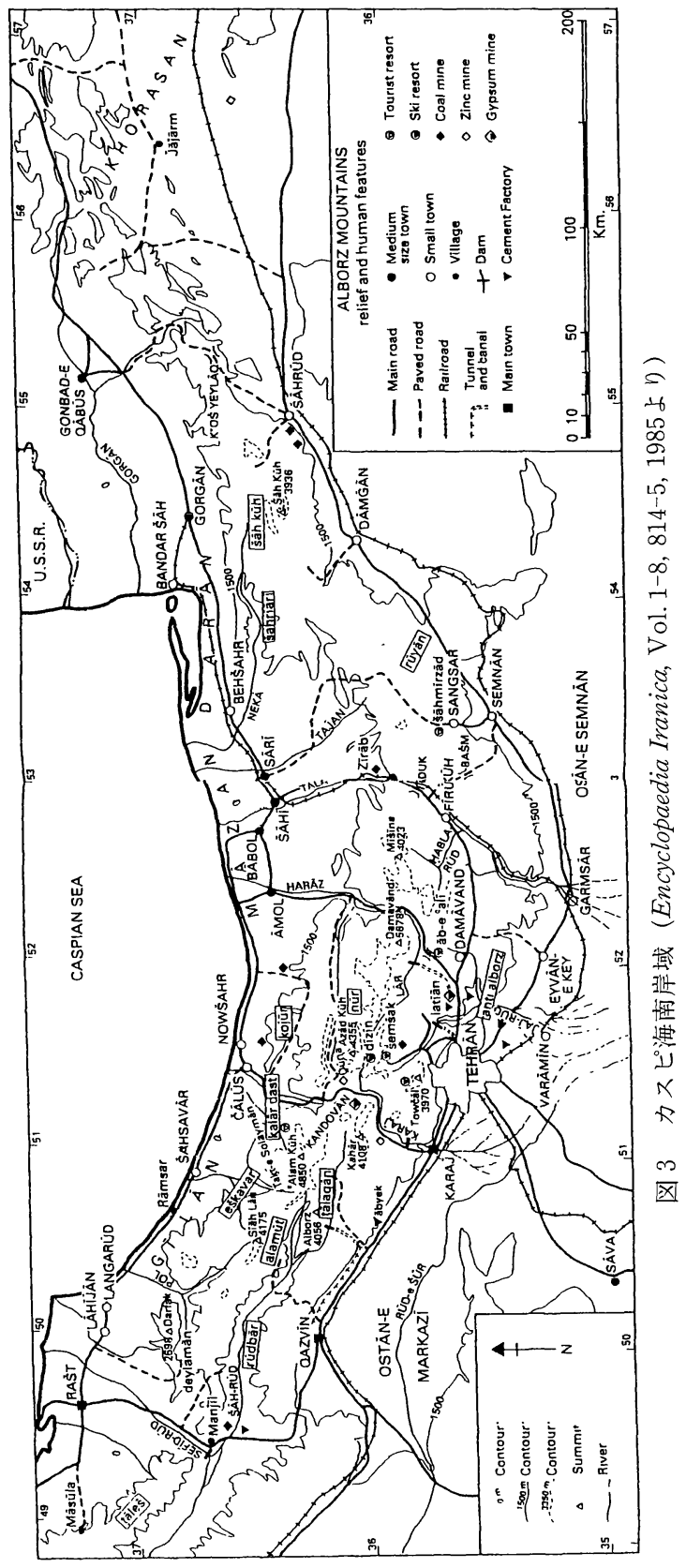




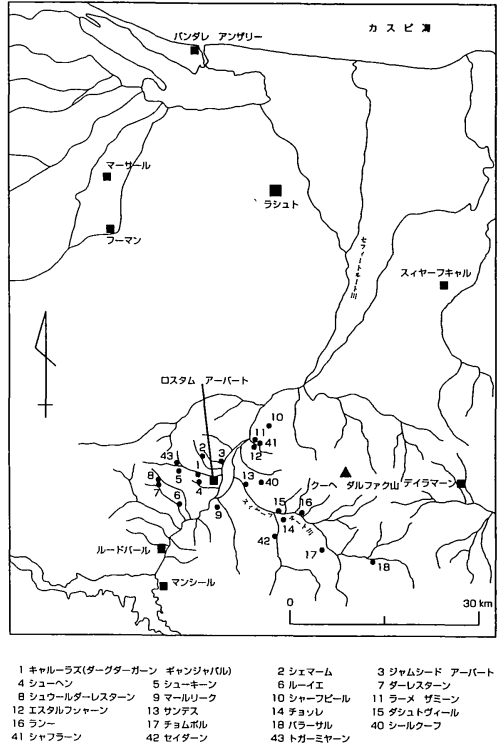

図 4 セフィードルード川流域遺跡分 布図 (大津, 岡野編2000, 22より)

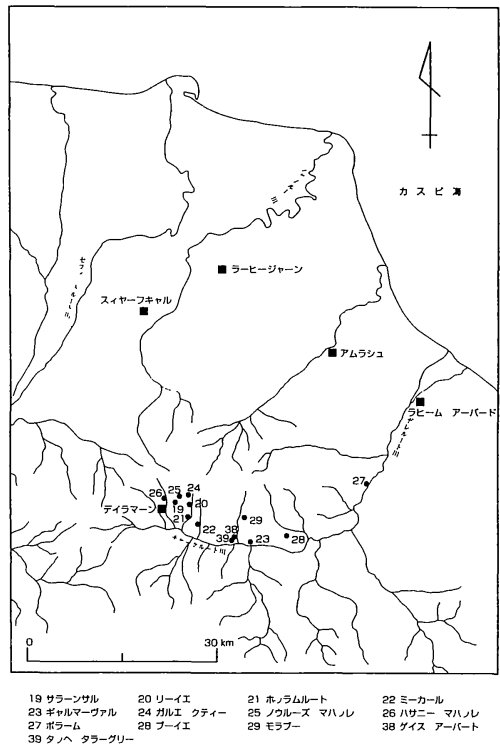

図 5 デイラマーン地域遺跡分布図 (大津，岡野編2000，28より)

いて改めて見直しておきたい。

ひとつは，セフィードルード川沿に位置するキャルーラズ遺跡ならびにマールリーク 遺跡に関してである。前者は革命前の数次にわたる発掘調査成果によって, 紀元前 2 千 年紀後半からサーサーン朝ペルシア時代にかけての群集墓（堅穴式土壙墓，竪穴式石槨 墓，地下式横穴墓）や建造物の基礎石列（?）等が見い出された。ただ，それら墓域の 範囲や建造物遺構との関係などは依然不明瞭なままであるために，さきのギーラーン大 地震復旧事業に伴う緊急調査 (1991年) 以降も, ウマの埋葬墓を含む古墓の偶発的発見が 相次いでいる状況にある。このキャルーラズ遺跡において，これら古墓の集中する地域 に隣接して, 遺物の散布具合と形状から「タッぺ (遺丘)」と判断しうる遺跡が 1 基存在 するのである(図 6 )。かねてよりギーラーン州内には，文化層の累積が形作るいわゆる タッぺは無いとされてきた。キャルーラズ遺跡の発掘調査者ハーキャミーはこのことに ついて，「時代が変わろうと敢えてひとところに留まる必要性のない好適な自然風土」が 当該地域における「異なる生活層」の形成をみせなかったのだ，と論じたほどであった。 はたしてキャルーラズ遺跡に近接する丘がまさしくタッぺであるならば，これまで検出 されてきている墓域との関連性が改めて問い直されねばならないし，またかつての発掘 調査時に検出の「基礎石列」の性格も再考されねばならない。当遺跡の位置する「キャ 


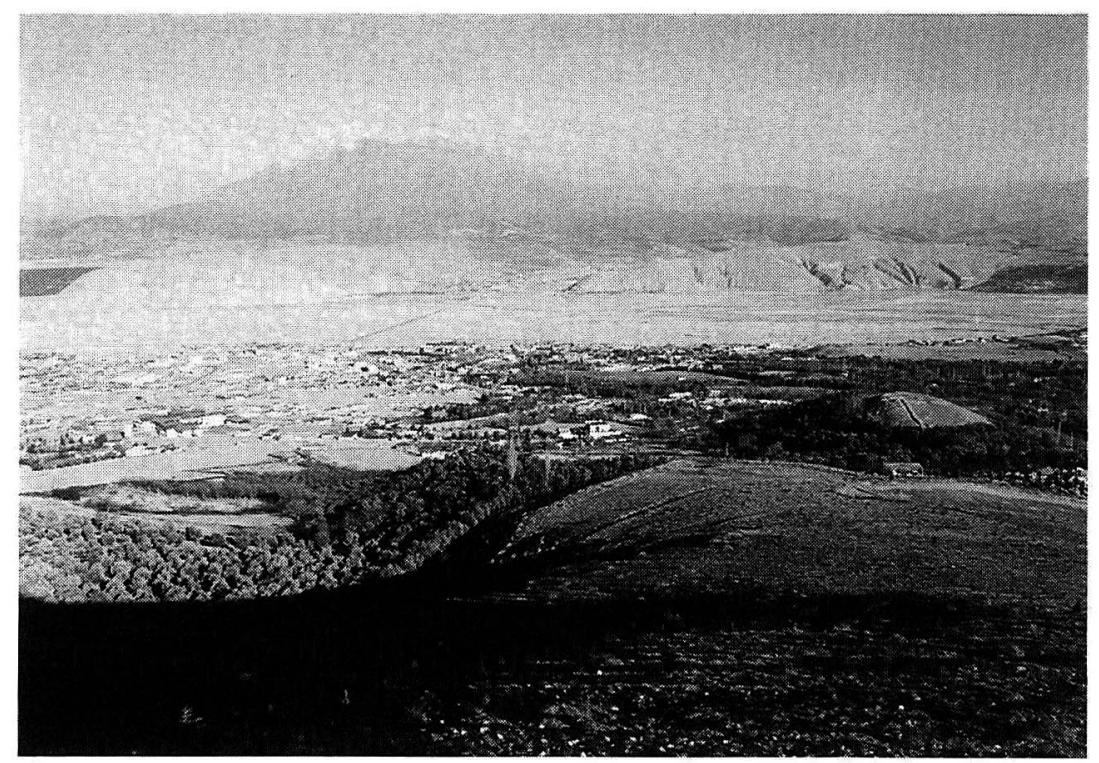

図 6 キャルーラズの「タッペ」(写真中央右寄)

ルーラズの谷」はセフィードルード川に連なる多数の谷筋のうちでも最大級の規模であ り，キャルーラズ川谷を遡行してそのかなり高所までジューキン，ドガーミヤーンなど 遺跡の所在が認められる。キャルーラズ遺跡はこの谷筋の最下に位置し，そしてセフィ ードルード川を挟んで相対峙するのがマールリーク遺跡である。豊かな副葬品の発見か ら王侯クラスの墓とも考えられているマールリーク遺跡は, 東側よりセフィードルード 川に連なる谷筋が大きく開けてはじめての，しかもこの大河に直面するところにある。 いわばこれらふたつの遺跡はいずれも川沿いの要衝を占めて位置するとみなすことがで きよう。セフィードルード川流域における遺跡分布調査が近年進展することによって， それまで出土品の豊かさに偏って注視されがちであった遺跡が, 周辺遺跡との関連に留 意して改めて問い直されねばならない新なな段階のもとに再提示されてきていると考え られる。

前記のハーキャミー論にみられるような当該地域における「タッぺ」の有り様を再考 しようとする時, ネギャフバーンがかつてアルボルズ山脈中で行った分布調査成果に関 (11) する最近の報告は興味深い。氏は, チャールス（マーザンダラーン州）の西南域をカス ピ海へ流れ下るサルドアブルード川上流域のキャラールダシュトから東南のマルザナバ ードにいたる渓谷の遺跡分布調査によって, 200地点以上の考古学的遺跡 (イスラーム期 の記念建造物を含む）を確認した。そのなかには, 具体的に何基存在するかについての 
言及はないものの, 表採土器資料の帰属時期によって 3 分類された「mound」タイプの 遺跡が含まれる。ネギャフバーンは，マールリーク遺跡のような「自然丘」についても もちろん「タッペ (テペ)」と呼称しているので, 氏の分布調査の対象となった「mound」 が，いわゆる生活層の累積によって形成されるタッぺすなわち「遺丘」を指しているか 否かについては慎重であらねばならないが, アルボルズ山脈西寄部における「mound」 タイプの遺跡の報告は，この事例がほとんど始めての報告というばかりでなく，ほぼ類 似の環境下にあるギーラーン州においても同様に捜し求め得る可能性があるのではない かとの期待を覚えさせ，ここに先のキャルーラズの「夕ッぺ」がいよいよ重要視されね ばならない理由のひとつがある。周知のごとく, カスピ海南岸のうち東寄り地域たとえ ばゴルガーン平原は「中近東の全域を通じてあまねく知られているような遺丘」の稠密 地帯であり，カスピ海南岸の西寄り地域とは随分とその様相を異にしている。東西の差 異はほぼマーザンダラーン州東部のサーリ付近にその境界線が引けそうである。キャル ーラズのタッペおよびキャラールダシュトから東南のマルザナバードにいたる渓谷から の報告事例がこの境界線を移動させ得るか否かは, 今後の調査あるいは報告にかかって いる。当該地域でこのように「タッぺ」の有無が問題にされなければならないのはこ れまで往々言及してきたように，現況ごく限られた種類，時期の遺跡しかこれまでには 判明していないからである。すなわち古墓以外の遺跡形態のひとつとして「夕ッペ」の 存在が注目できるのではないか, との希望的観測なのである。

さて「紀元前 $2 \sim 1$ 千年紀を遡る遺跡」はどうかというもうひとつの問題がある。こ れについては, 古墓以外の遺跡形態例の一候補であることと共に, さきに言及した石灰 岩洞窟遺跡が注意されねばならないであろう。カスピ海南岸地帯ではかつてクーンが旧 石器時代までさかのぼるホトゥ洞窟やベルト洞窟（マーザンダラーン州）を調査して以 降, 革命前すでにいくつかの洞窟遺跡が調査対象になっていた。アルボルズ山脈中の豊 富な石灰岩は, カスピ海沿岸における港湾整備事業のための資材のひとつとして採取さ れ続けてきたので, その過程で洞窟遺跡が明らかになったりあるいは消滅したらしいと ころがある。最近の新発見例で注目されたのは, マーザンダラーン州ネカー近郊に位置 するクミシャーン洞窟であった（図 7，8)。イラン当局の報告を要約解説した山内によ れば,この洞窟は「中石器時代から紀元前11〜12世紀まで使用されたものと推測されてい る」。これとともにサルドアブルード川上流域における調査成果報告が注意されねばな らないであろう。ネギャフバーンは，12地点において洞窟遺跡を確認した由。それぞれ の洞窟はそれらの入口部にかなりの堆積物を有し, 石刃や粗製の石器を包含していた。 同報告文中に言う「古代社会の他地域の居住者たちが, すでに新石器時代や定住村落農 耕段階を通り過ぎて銅石器時代に移った時も，(サルドアブルード川流域では）洞窟居住 


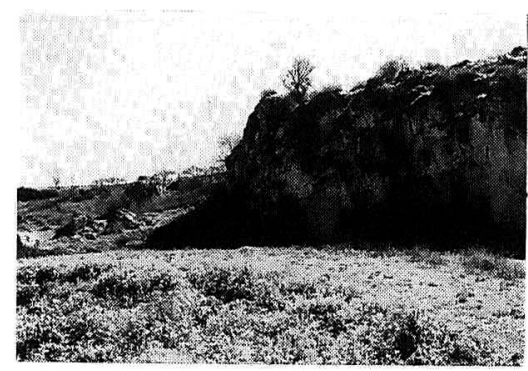

図 7 クミシャーン洞窟（洞窟開口部は 現在封鎖されている)

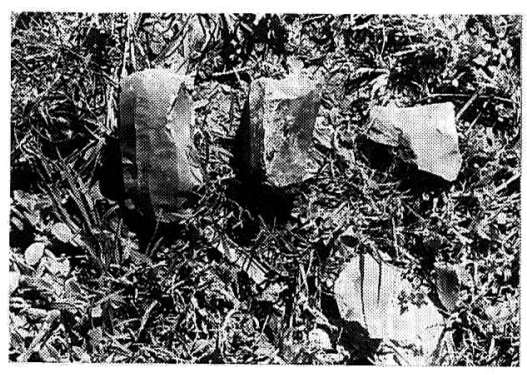

図 8 クミシャーン洞窟近辺に散布する 石器 (石刃核, 剥片など)

生活が続けられていた」との見解は, 石器時代に限ることのない洞窟の使用例において 先のクミシャーン洞窟と相共通する可能性を窺わせている。すなわち洞窟に遺跡を捜し 求めようとする場合, 我が国でも行われるように, つい最近まであるいは現在なんらか の用途で機能している洞窟は，おおいにその可能性があることを実証する二例なのであ る。中近東文化センターによるギーラーン州踏查期間中聴き知ったかぎりでは，石灰岩 洞窟に遺跡の可能性を想定して探查を試みようとする姿勢は, 地域によって当局ごとの 差異が大きい。カスピ海南岸域に限らず，政治的要因からたまたま報告に乏しかった遺 跡事例が，少しずつながら着実に数を加えている。きつと期待して良いであろう旧石器 時代に遡る洞窟遺跡の発見は，これまでの当該地域における遺跡の有り様の不自然さを 見直す端緒となると考えられる。

まとめにかえて一遺跡の分布状況を如何様にみるか一

ターレシュ/アルボルズ山系のうちカスピ海に面する範囲（ギーラーン州，マーザン ダラーン州西奇部) では, 石器時代に遡る遺跡の存在や古墓以外の種類の遺跡が不祥と いう遺跡の有り様における不自然さが問題として存在する。なぜこれまで充分に問題と されてこなかったのかということについては, 敢てここではふれないが, 周辺との関連 性を考虑するうえでも明確にすべき課題であろう。すなわち石器時代に遡る遺跡の存在 につては, かつてクーンがイランの諸洞窟を含む一連の中近東洞窟遺跡調査研究にのつ とり提唱した人類拡散ルート上に当該地域があること（図 9 ), あるいはまた, デイラマ ーンの「ラスルカン遺跡」(=サラーンサル遺跡) 第二層については「土器を全然伴出し ない」,「土器以前の文化段階」,「プレ・セラミックの段階」が注意されそして「竪穴遺構」 や「配石遺構」の検出されていたことなどははやくに問題提起されたが，具体的進展に はいまもってそしく，再考されるべく残された課題のままなのである。今後これらを考 


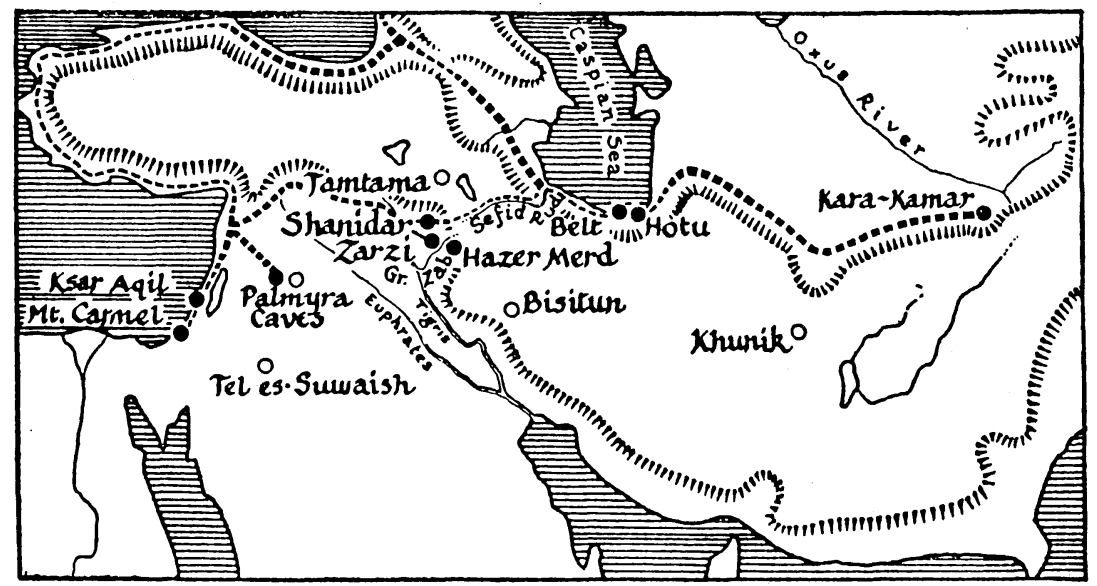

図 9 クーンの唱えた石器時代人類東漸経路 (Coon 1957, 296より)

察しようと試みるならば，考古学調査の常套として，どこにどのような遺跡が存するか についての信頼できる踏査データ作成が先ずは不可欠となる。実際現地に立つと，先の マールリーク遺跡とキャルーラズ遺跡が川を挟んで相対峙するのは, セフィードルード 川が山間から流れ出てのちはじめて地勢の大きく開けるところであることが認識できる。 この流域についてはイラン人研究者による遺跡分布調查の成果発表があり, 中近東文化 センターによる分布調査成果とともに，古代の墓域の立地や分布状況を当該地方にいま でもみられる「垂直方向の移牧」との関連性から見直す試案を提示する基となっている。 また，このセフィードルード川側からみればデイラマーンも，険しい谷筋に入り込んで 後はじめて地勢の開ける盆地に位置することがわかる。一見隔絶の観があるものの古墓 より出土する副葬品土器, 青銅器資料には相共通するところが多いこと, そればかりか さらに東方のゴルガーンやダームガーン近边出土土器のなかにデイラマーン出土の土器 と同じ範疇に属するものが多く認妨れると先。セフィードルード川が，カスビ海南 岸域とイラン高原とをむすぶ一大要路としてアルボルズ山系を縦断するばかりでなく， マンジールにおいて西北からの流れ（ギジィルウズン川）と東南からのながれ（シャー フルード川）と合流し，山系を横走する渓谷沿の経路を形成していることに無関係では あるまい。キャラールダシュトもサルドアブルード川上流に開けた山間域であるが，こ れもアルボルズ山系縦断路のひとつ，すなわち北流するチャールス川と南流するカラジ 川とが開くチャールス／カラジ間路に連なって位置している。このような地域で，地勢 的経路を考慮に入れそして問題意識を明確にもった分布調查が綿密になされれば，ター レシュ/アルボルズ山系のカスピ海に面するところにも，これまで述べてきたようない 
くつかの先例あるいは隣接域の諸例から類推して, 先史時代の明確な証跡が見い出せる であろう。

なお，当該域が湿潤地带であることが遺跡の有り様にどう関係するのかについては， 別の機会に譲りたい。

（本稿は，2000年度オリエント学会大会発表内容に加筆したものである。また，日本西 アジア考古学会第 5 回大会における研究発表内容と一部重複することをお断りしておき たい。)

\section{注}

（1）大津忠彦，山内和也「イラン考古学の最近の動向」『オリエント』38/1 (1995), 199211.

（2）大津忠彦「イラン踏査」『MECCJ』nos. 1-6 (1992-1997).

（3）中近東文化センター『ギーラーン一緑なすもう一つのイラン一』, 1998 ; 大津忠彦, 岡野智彦編著『ギーラーン踏查一1997，1998年度イラン遺跡踏査の記録一』，2000.

(4) P. E. L. Smith, Palaeolithic Archaeology in Iran, Philadelphia, 1986.

（5）大津忠彦「ギーラーン州の古代遺跡一その発現と考古学的アプローチをめぐ って一」『ギーラーン一緑なすもう一つのイラン一』所収.

(6 ) H. de Morgan, "Recherches au Talyche Persan en 1901," Mémoires de la Délégation en Perse 8, Paris, 1905.

(7) C. F. A. Schaeffer, Stratigraphie Comparée et Chronologie de l'Asie Occidentale, London, 1948.

R. H. Dyson, Jr., "The Archaeological Evidence of the Second Millennium B. C. on the Persian Plateau," in I. E. S. Edwards et al. (eds.), The Cambridge Ancient History (3rd ed.) Vol. 2, Pt. 1, Cambridge, 1973.

江上波夫「タリシュのドルメン文化」『アジア文化史研究 要説篇」, 1965.

(8) H. Sadek-Kooros, "Early Hominid Traces in East Azarbaijan," Proceedings of the IVth Annual Symposium on Archaeological Research in Iran, Tehran, 1976.

(9) A. Hakemi, "Kaluraz and the Civilization of the Mardes," Archaeologia Viva, no. 1, Paris, 1968.

id., "Excavations in Kaluraz," Bulletin of the Asia Institute of the Pahlavi University, Shiraz, 1973.

(10) Hakemi, 1973.

(11) E. O. Negahban, Marlik The Complete Excavation Report, 2 vols., Philadelphia, 1996.

(12) V. E. Crawford, "Beside the Kara Su," Bulletin of the Metropolitan Museum of 
Art, Vol. 21, no. 5, New York, 1963.

(13) C. S. Coon, Cave Exploration in Iran, Philadelphia, 1949.

id., Seven Caves-Archaeological Exploration in the Middle East-, London, 1957.

C. B. M. McBurney, "Preliminary Report on Stone Age Reconnaissance in North-eastern Iran," Proceedings of the Prehistoric Society, n. s. Vol. 30, Cambridge, [1964].

（14）山内和也「イラン考古学の新発見」『古代オリエント博物館紀要』17 (1996).

（15）注(11)を見よ。

(16) 注(13)の Coon 1957.

（17）江上波夫編著『デーラマン I 一ガレクティ・ラスルカンの発掘一』，1965.

（18）千代延惠正「デイラマーン再考」2000，大津，岡野編 2000所収.

（19）山内和也「ギーラーン・セフィードルード西岸の古墓群について」『日本西アジア 考古学会第 4 回総会・研究発表会』, 1999.

同「セフィードルード川両岸の古墓群について一垂直方向の移牧からのアプロー チ一」2000, 大津, 岡野編 2000所収.

(20) 注(18)の千代延 2000 . 